\title{
Autosomal recessive primary microcephaly $(\mathrm{MCPH})$ : clinical manifestations, genetic heterogeneity and mutation continuum
}

\author{
Saqib Mahmood ${ }^{1}$, Wasim Ahmad ${ }^{2}$ and Muhammad J Hassan ${ }^{3^{*}}$
}

\begin{abstract}
Autosomal Recessive Primary Microcephaly (MCPH) is a rare disorder of neurogenic mitosis characterized by reduced head circumference at birth with variable degree of mental retardation. In MCPH patients, brain size reduced to almost one-third of its original volume due to reduced number of generated cerebral cortical neurons during embryonic neurogensis. So far, seven genetic loci (MCPH1-7) for this condition have been mapped with seven corresponding genes (MCPH1, WDR62, CDK5RAP2, CEP152, ASPM, CENPJ, and STIL) identified from different world populations. Contribution of ASPM and WDR62 gene mutations in MCPH World wide is more than 50\%. By and large, primary microcephaly patients are phenotypically indistinguishable, however, recent studies in patients with mutations in MCPH1, WDR62 and ASPM genes showed a broader clinical and/or cellular phenotype. It has been proposed that mutations in $\mathrm{MCPH}$ genes can cause the disease phenotype by disturbing: 1) orientation of mitotic spindles, 2) chromosome condensation mechanism during embryonic neurogenesis, 3) DNA damageresponse signaling, 4) transcriptional regulations and microtubule dynamics, 5) certain unknown centrosomal mechanisms that control the number of neurons generated by neural precursor cells. Recent discoveries of mammalian models for MCPH have open up horizons for researchers to add more knowledge regarding the etiology and pathophysiology of MCPH. High incidence of MCPH in Pakistani population reflects the most probable involvement of consanguinity. Genetic counseling and clinical management through carrier detection/prenatal diagnosis in MCPH families can help reducing the incidence of this autosomal recessive disorder.
\end{abstract}

Keywords: Heterogeneity, Mutations, Pakistan, MCPH

\section{Introduction}

In this article, we have reviewed the clinical and molecular genetics studies of autosomal recessive primary microcephaly (MCPH). This review article has been divided into three main sections. In the first part, we have discussed the clinical manifestations of the disease. In second part, molecular genetics of autosomal recessive primary microcephaly including a comprehensive appraisal of the seven mapped loci (MCPH1 - MCPH7), their corresponding genes, protein products of the genes, their likely role in normal brain development and the details of the mutations reported in these genes, especially with reference to Pakistan, have been

\footnotetext{
* Correspondence: hassanraja12@hotmail.com

${ }^{3}$ Department of Biochemistry, University of Health Sciences, Khayaban-eJamia Punjab, Lahore, 54600, Pakistan

Full list of author information is available at the end of the article
}

reviewed. Lastly, probable involvement of $\mathrm{MCPH}$ genes in the evolution of human brain to perform diverse cognitive functions has been apprehended.

\section{Clinical Manifestations}

Autosomal Recessive Primary Microcephaly (MCPHMIM 251200) is a developmental defect of brain characterized by congenital reduction in head circumference of at least 2 standard deviations (SD) below ethnically matched, age- and sex-related mean and non-progressive mental retardation of variable degree, in absence of any significant neurological deficit [1-8]. Microcephaly in $\mathrm{MCPH}$ is primary i.e. it is evident by $32^{\text {nd }}$ week of gestation, is present at birth, and is non-progressive $[4,5,9,10]$. Head circumference (HC) or occipitofrontal circumference (OFC) is the most common diagnostic tool for $\mathrm{MCPH}$. It has been observed that $\mathrm{HC}$ ranges

\section{Ciomed Central}


from $2 \mathrm{SD}$ to $11 \mathrm{SD}$ below the mean in $\mathrm{MCPH}$ patients with very mild interfamilial difference in degree of microcephaly $[8,11-13]$. By using the definition of $\mathrm{HC} 3$ $\mathrm{SD}$ or below the mean, MCPH patients with normal intelligence are very rare $[14,15]$. Most of the $\mathrm{MCPH}$ patients are easy-to-handle and can acquire several selfhelp skills. An indistinguishable sloping forehead is present in many cases but not always found to be associated with MCPH $[11,16,17]$. Seizures and epilepsy have been found in higher frequency in patients with ASPM mutations, but are very rarely found in patients affected due to other $\mathrm{MCPH}$ genes, and are no more common than in general population $[4,8,12,18]$. Table 1 gives a description of phenotypes for $\mathrm{MCPH}$ patients.

\section{Do MCPH1, WDR62 and ASPM mutations result in different} phenotype?

Earlier, based on the findings of several studies by different groups on more than 200 families world-wide, it was believed that specific physical appearance of patients linked to each MCPH locus is indistinguishable $[11,12,16,17,19,20]$. Also, chromosomal analysis for most of the MCPH patients was reportedly normal [12]. But recent studies, supported by modern neurodiagnostic modalities like of Computed Tomography (CT) Scan and Magnetic Resonance Imaging (MRI), have significantly increased our knowledge regarding the discernible clinical presentations of $\mathrm{MCPH}$ and expanded the definition of $\mathrm{MCPH}$ based on phenotype $[4,21,22]$.

For $M C P H 1$ related $\mathrm{MCPH}$ patients, in addition to relatively small height, high proportion of prophase-like cells due to premature chromosome condensation is reported [23-25]. In case of MCPH2 gene (WDR62) mutations, a broad clinical phenotype in MCPH patients has been observed by three independent research groups $[21,26,27]$. It includes microcephaly, pachygyria with cortical thickening as well as hypoplasia of the corpus callosum. In some patients, presence of lissencephaly, schizencephaly, polymicrogyria and, in one instance cerebellar hypoplasia has been observed. These were previously regarded as distinct entities from $\mathrm{MCPH}$ [26,27].

A recent study has clinically evaluated patients with ASPM mutations and showed several additional phenotypes. They include border-line microcephaly and intelligence quotient (IQ) scores, mild epilepsy, late-onset seizures, simplified gyral pattern, ventricle enlargement, partial corpus callosum agenesis, and mild cerebellar hypoplasia [8]. In another report, MRI imaging of the brain of MCPH patients with ASPM mutations revealed simplified anterior gyral pattern with reduced white matter, but without any evidence for a neuronal migration defect $[28,29]$.

\section{Molecular Genetics of MCPH Incidence of $\mathrm{MCPH}$}

As reported in birth defect registers world-wide, the incidence of microcephaly varies from 1.3 to 150 per 100,000 depending upon the type of population and the range of SD used to define microcephaly [30-33]. It has been found that $\mathrm{MCPH}$ is more common in Asians and Arabs than in White; a white (non-consanguineous) $\mathrm{MCPH}$ incidence is 1 per million as compared to $1 / 100,000$ in consanguineous populations like Pakistan $[1,4,34]$.

\section{Genes in $\mathrm{MCPH}$}

$\mathrm{MCPH}$ is thought to be a disorder of neurogenic mitosis due to the fact that most of the genes implicated in the etiology of $\mathrm{MCPH}$ are involved somehow in mitosis and are expressed in neuroepithelium during embryonic neurogenesis [3]. Understanding the neuro-developmental etiology leading to $\mathrm{MCPH}$ is of high significance for understanding the brain development and mammalian evolution with a massive increase in size of the cerebral cortex in primates. Genetic heterogeneity is well established in $\mathrm{MCPH}$ and so far seven loci (MCPH1MCPH7) have been discovered, named according to their order of discovery [35-42]. Mutations in seven genes with in these loci have been identified (Table 2).

Table 1 A depiction of clinical symptoms associated with MCPH

\begin{tabular}{|c|c|}
\hline MCPH features associated with Apparent phenotype & MCPH features associated with MRI-based/cellular phenotype \\
\hline $\begin{array}{l}\text { Microcephaly (at least } 2 \text { SD below the mean) at birth, mild to severe, } \\
\text { non-progressive mental retardation (borderline IQ is possible). }\end{array}$ & $\begin{array}{l}\text { Reduction of cerebral cortical volume (neuronal proliferation defect) and } \\
\text { simplification of gyral pattern in most cases }\end{array}$ \\
\hline $\begin{array}{l}\text { Epilepsy/fits/seizures are very rare but cannot exclude the diagnosis } \\
\text { (ASPM) }\end{array}$ & $\begin{array}{l}\text { Premature chromosome condensation in some cases with increased } \\
\text { prophase-like cells }(\mathrm{MCPH})\end{array}$ \\
\hline Sloping forehead is although common but is not always associated & $\begin{array}{l}\text { Pachygyria with cortical thickening as well as hypoplasia/agenesis of the } \\
\text { corpus callosum (neuronal migration defect) in some cases (ASPM, WDR62) }\end{array}$ \\
\hline Delay in early motor milestones (Speech delay is common) & $\begin{array}{l}\text { In few cases Lissencephaly, schizencephaly, polymicrogyria and, cerebellar } \\
\text { hypoplasia have also been observed (WDR62) }\end{array}$ \\
\hline \multicolumn{2}{|l|}{$\begin{array}{l}\text { Some times aggressive but otherwise have a happy effect (easy to } \\
\text { handle) }\end{array}$} \\
\hline Short stature in some cases (MCPH1) & \\
\hline
\end{tabular}


Table 2 A brief description of known MCPH loci/genes so far

\begin{tabular}{|c|c|c|c|c|c|}
\hline Locus & Chromosome & Gene & Cellular location & Proposed Function & References \\
\hline$\overline{\mathrm{MCPH} 1}$ & $8 p 23$ & $\begin{array}{c}\text { MCPH1 } \\
\text { Microcephalin }\end{array}$ & Nucleus/Chromatin & DNA Damage repair, chromosome condensation & {$[39,52,58]$} \\
\hline $\mathrm{MCPH} 2$ & $\begin{array}{l}19 q 13.12- \\
q 13.2\end{array}$ & WDR62 & $\begin{array}{l}\text { Nucleus, cetrosomal during } \\
\text { mitosis }\end{array}$ & $\begin{array}{l}\text { Not yet established, expression pattern resembles with } \\
\text { ASPM }\end{array}$ & {$[21,26,27,40$} \\
\hline $\mathrm{MCPH} 3$ & $9 q 33.2$ & CDK5RAP2 & Centrosome/Midbody & $\begin{array}{c}\text { Regulation of microtubule function/Centrosome } \\
\text { maturation }\end{array}$ & {$[44,62,63]$} \\
\hline MCPH4 & $15 q 15-q 21$ & CEP152 & Centrosome & Involved in centriol duplication & {$[41,46]$} \\
\hline MCPH5 & $1 \mathrm{q} 31.3$ & ASPM & Pericentrosomal/Midbody & $\begin{array}{c}\text { Orientaion of mitotic spindles during embryonic } \\
\text { neurogenesis }\end{array}$ & {$[22,67,71,79$} \\
\hline MCPH6 & $13 q 12.12$ & CENPJ & Centrosome/Midbody & Centriole length control/microtubule function & {$[44,86,87]$} \\
\hline MCPH7 & $1 p 33$ & STIL & Pericentrosomal & Spindle organization/Cell cycle progression & {$[42,96-100]$} \\
\hline
\end{tabular}

The ASPM gene at MCPH5 locus and WDR62 at $\mathrm{MCPH} 2$ locus have been found mutated in more than $55-60 \%$ of the MCPH families jointly, while CDK5RAP2 gene at $\mathrm{MCPH} 3$ locus has least involvement in causing $\mathrm{MCPH}[3,4,11,43]$. Many of these genes have been found mutated in families from Pakistan with CDK5RAP2 mutations found in Pakistani families only [43-45]. Model organisms like Drosophila, Mouse and Zebra fish have been extensively used to study the effects of mutations in different human $\mathrm{MCPH}$ genes. Table 3 gives a brief description of animal models for $\mathrm{MCPH}$ genes.

A detailed description of the MCPH gene mutations, their most likely functions in causation of the disease and animal model studies of MCPH genes is as follows.

\section{1- Microcephalin (MCPH1)}

MCPH1/microcephalin gene (MIM 607117) at chromosome 8 p23 contains 14 exons and 835 amino acids; the genomic size is $241905 \mathrm{bp}$ with three isoforms reported so far and 8032 bp Open Reading Frame [25,46]. Microcephalin, the encoded protein is implicated in DNA damage induced cellular responses and chromosome condensation. This protein is considered to have a role in $\mathrm{G} 2 / \mathrm{M}$ checkpoint arrest via maintenance of inhibitory phosphorylation of cyclin-dependent kinase 1 [3]. The first mutation in $M C P H 1$ gene was found in $\mathrm{MCPH}$ families from Pakistan [25]. Later mutation in this gene was reported in a disorder of microcephaly, short stature and misregulated chromosome condensation, known as Premature Chromosome Condensation Syndrome (PCC). It was therefore discovered that both MCPH1

Table 3 Tabular representation of MCPH animal models

\begin{tabular}{|c|c|c|c|}
\hline $\begin{array}{l}\text { Human Gene } \\
\text { for MCPH }\end{array}$ & $\begin{array}{l}\text { Animal Ortholog/s of } \\
\text { Human Gene }\end{array}$ & Animal Model Phenotype & References \\
\hline $\begin{array}{l}\text { MCPH1 } \\
\text { /Microcephalin }\end{array}$ & $\begin{array}{l}m \text { mph }^{-1-} \text { (drosophila/ } \\
\text { mice) }\end{array}$ & $\begin{array}{c}\text { Reduced protein recruitment to centrosomes and formation of abnormal spindles, } \\
\text { missegregation of DNA, aberrant cytokinesis, changes in cell-cycle progression and defects } \\
\text { in DNA damage repair. Adult brain sizes are reported to be normal in drosophila and } \\
\text { infertility has been shown in mice }\end{array}$ & {$[1,45,56,59]$} \\
\hline CDK5RAP2 & $\mathrm{Cnn}^{-/-}$(drosophila) & $\begin{array}{l}\text { Centrosome dysfunction loss of connection between Centrosomes and pericentriolar matrix) } \\
\text { Only subtle defects of asymmetric divisions and Brains are reportedly of normal size }\end{array}$ & {$[1,45,68]$} \\
\hline$A S P M$ & $\begin{array}{l}\operatorname{asp}^{-/}(\text {drosophila }) \\
\left.\text { Aspm }^{-/} \text {(mice }\right)\end{array}$ & $\begin{array}{l}\text { (drosophila) incorrect centrosome as microtubule-organizing center, mitotic spindle } \\
\text { positioning defect, cell cleavage plane positioning defect during asymmetric cell division } \\
\text { and spermatogenesis defect (mice) defects in meiosis I and II, affecting the coordination of } \\
\text { chromosome segregation and spindle positioning, transgene rescues the microcephaly } \\
\text { phenotype but does not produce a gain of function. reduce fertility in males and females } \\
\text { mice but do not alter copulation frequency. }\end{array}$ & {$[1,45,82-84]$} \\
\hline CENPJ & $\begin{array}{l}\text { SAS }-4^{-1-} \text { (drosophila, c. } \\
\text { elegans) }\end{array}$ & $\begin{array}{l}\text { (drosophila) loss of centrioles, abnormal spindle formation and DNA segregation defects. } \\
\text { Mutant flies develop into morphologically normal adults without cilia or flagella and die } \\
\text { shortly after birth (c. elegans) loss of centrioles, abnormal control of centrosome size } \\
\text { (centrosome organization) }\end{array}$ & {$[1,45,92-95]$} \\
\hline \multirow[t]{2}{*}{ STIL } & $\begin{array}{l}\mathrm{Sil}^{-1} \text { (mice) } \operatorname{csp}^{-1-} \text { (zebra } \\
\text { fish) }\end{array}$ & $\begin{array}{c}\text { (mice) knockout of SIL is embryonic lethal at E10.5. Between E7.5 and E8.5. the knockout } \\
\text { embryos are smaller, display pericardial swelling, midline neural tube defects, failure of } \\
\text { neural tube closure and holoprosencephaly. Failure in left-right specification. Due to block in } \\
\text { Sonic Hedgehog (Shh) signalling, and increased apoptosis }\end{array}$ & {$[1,98-100]$} \\
\hline & & $\begin{array}{c}\text { (Zebra fish) embryonic lethal with increased number of mitotic cells with defects including } \\
\text { mono-polar spindles, loss of polarity, misaligned chromosomes, and broadened spindle } \\
\text { poles. }\end{array}$ & \\
\hline
\end{tabular}


and PCC syndrome are allelic disorders originated from mutations with in the same gene [24]. More recently, Farooq et al, (2010) [47] described the CraniosynostosisMicrocephaly with Chromosomal Breakage (CMCB) and other abnormalities that were caused by a truncating mutation (302C-G) in exon 4 of the MCPH1 gene. CMCB is found to be allelic to PCC syndrome and MCPH1.

A missense mutation has been reported in $M C P H 1$ gene demonstrating less severe cellular phenotype and mild microcephaly [4,23]. Also, a large deletion mutation encompassing first 6 exons of Microcephalin gene in an Iranian family, showing autosomal recessive mental retardation and mild microcephaly, has been reported [48].

Microcephalin contains three (one N-terminal and two C-terminal) BRCT domains (Carboxy-terminal domain of breast cancer gene BRCA1); ortholog genes with similar domain structures are also found in model organisms such as the mouse, Drosophila melanogaster and Caenorhabditis elegans [49]. The BRCT domains are evolutionarily conserved phosphor-peptide binding amino acid tandem repeat domains involved in cell cycle control. Expression studies show high levels of Microcephalin expression localized to the developing forebrain and, in particular, to the walls of the lateral ventricles in fetal brain $[49,50]$. The gene was also shown to be expressed in fetal mouse brain during neurogenesis, with highest expression in the ganglionic eminences and lateral ventricles [25]. However, it is also expressed at similar levels in many other fetal tissues such as liver and kidney and, at lower levels, in other tissues.

Cell cycle checkpoints, the regulatory pathways that govern the order and timings of cell cycle transition, are inter related with DNA damage response signaling pathways as cell cycle has to be arrested until damage is repaired. A role for microcephalin in DNA damage response was confirmed after the demonstration that microcephalin localizes to DNA repair foci and that cells depleted for microcephalin by RNA interference exhibit failure in cell cycle checkpoints [51]. It has been proposed that mutations in microcephalin are a causal link between impaired DNA damage response signaling and microcephaly and that misregulated chromosome condensation in MCPH1 is mediated by condensin II protein [52,53]. Wood et al (2007) [54], demonstrated that microcephalin protein is recruited to double-strand breaks via interaction of its C-terminal BRCT domains with phosphorylated $\mathrm{H} 2 \mathrm{AX}$, a histone variant that marks sites of damaged DNA, further expanding the signal to CHK1 and CHK2 via subsequent phosporylation, leading to the modulation of cell cycle, DNA repair and apoptosis.
Alderton et al (2006) [55] found defective G2/M checkpoint arrest, nuclear fragmentation after DNA damage, and supernumerary mitotic centrosomes in human lymphoblastoid cell lines with different truncating mutations in $M C P H 1$. They concluded that MCPH1 has a role in maintaining inhibitory CDK1 phosphorylation, which prevents premature entry into mitosis. Thus, microcephaly occurring in patients with MCPH1 mutations may be due to a defective centrosomal function of microcephalin, influencing the number of proliferative cell divisions of neuronal stem cells in neurogenesis.

Brunk et al (2007) [56], and Rickmyre et al (2007) [57], have used Drosophila to evaluate the effects of mcph1 deficiency. The cellular phenotypes include uncoordinated centrosome and nuclear cycles, slowed mitotic entry, premature chromosome condensation, mitotic entry with un-replicated DNA, genomic instability, premature separation and centrosome detachment. They also noted chk2-mediated mitotic arrest in the Drosophila cells with mcph1 deficiency. Surprisingly, the adult brains were of normal size but have defects in mushroom body structure.

Recently, two research articles claim the success in generation of mouse model for $M C P H 1$ related primary microcephaly. Trimborn et al, (2010) [58], reported the first mammalian model with mis-regulated mitotic chromosome condensation due to defective Mcph1 function. Although residual wild type allele could be detected by quantitative real-time PCR, cell cultures generated from mouse tissues bearing the homozygous gene trap mutation display the cellular phenotype of misregulated chromosome condensation that is characteristic for the human disorder; thus confirming defective Mcph1 function due to the gene trap mutation. While surprisingly the DNA damage response (formation of repair foci, chromosomal breakage, and G2/M checkpoint function after irradiation) appears to be largely normal in cell cultures derived from Mcph $1^{\text {gt/gt }}$ mice, the overall survival rates of the Mcph $1^{\mathrm{gt} /}$ gt animals are significantly reduced compared to wild type and heterozygous mice. Moreover, the animals show no obvious physical phenotype and no reduced fertility.

Liang et al (2010) [59] also described the generation of Mcph1 deficient mouse model. They found that Brit1 ${ }^{-/-}$ (double negative mice) and mouse embryonic fibroblasts (MEFs) both were hypersensitive to c-irradiation. MEFs and T-lymphocytes exhibited severe chromatid breaks and reduced Rad51 foci formation after irradiation. Notably and in contrast to the findings of Trimborn et al (2010) [58], Brit1 double negative mice were infertile and meiotic homologous recombination was impaired. They observed that Brit1-deficient spermatocytes exhibited a failure of chromosomal synapsis, and a meiotic arrest was observed at late zygotene of prophase I accompanied by apoptosis. 


\section{2- WDR62 (MCPH2)}

The gene lies within the MCPH2 candidate linkage interval at chromosome 19q13.12 with 32 functional exons and genomic size of $50230 \mathrm{bp}[26,46]$. The gene has two predicted isoforms and the protein consisting of 1523 residues contains 15 WD repeats [46].

In three recently published research articles, authors have found recessive mutations in human WD repeat domain 62 gene (WDR62) in families showing linkage at $\mathrm{MCPH} 2$ locus. Authors have observed variety of severe cerebral cortical malformations in the affected individuals including microcephaly, pachygyria with cortical thickening as well as hypoplasia of the corpus callosum $[21,26,27]$. The authors reported that some patients with mutations in WDR62 had evidence of additional abnormalities including lissencephaly, schizencephaly, polymicrogyria and, in one instance, cerebellar hypoplasia, all traits traditionally regarded as distinct entities.

Bilguvar et al (2010) [26] have found 5 homozygous WDR62 mutations including deletions and premature terminations in patients suffering from microcephaly and some additional phenotypes, belonging to Turkish origin. Nicholas et al (2010) [27] have identified WDR62 as the second most common cause of MCPH after finding homozygous missense and frame-shifting mutations in seven MCPH families, including one from Pakistan. $\mathrm{Yu}$ et al (2010) [21] also identified six families with syndrome of congenital microcephaly and diverse defects in cerebral cortical architecture. They identified six mutations in WDR62 gene by use of targeted high throughput sequence analysis. In mice and humans, WDR62 expression is found in neural progenitors within the ventricular and subventricular zones. It is observed that expression of WDR62 in the neocortex is transient; spanning the period of embryonic neurogenesis [21]. According to the observation of authors, WDR62 does not apparently associate with centrosomes and is predominantly nuclear in localization [21]. But other researchers have found the expression pattern of WDR62 identical to that of ASPM; another MCPH protein expressed at and able to focus the spindle poles in neural precursor cells [26]. They have elaborated that in interphase cells, WDR62 had weak, diffuse cytoplasmic expression. During mitosis, WDR62 accumulated strongly at the spindle poles but was not present at the midbody in cytokinesis.

Another research group has shown that WDR62 demonstrates notable cell cycle-dependent localization. They have revealed punctate, perinuclear expression of WDR62 during interphase, suggesting localization to the Golgi apparatus, by immunofluorescence staining of endogenous WDR62 in HeLa cells with an anti-WDR62 antibody. In contrast, in HeLa or HEK cells in M phase, the authors have found the presence of WDR62 protein at the spindle poles, as demonstrated by double labeling with $\gamma$-tubulin and dynein [27].

These findings have suggested that mutations in WDR62 are involved in the pathogenesis of varying cortical abnormalities that until now have largely been conceptualized to be distinct and these diverse features can have unified underlying causation. Although there were no imaging studies presented in the previous mapping of this locus, recent findings by different groups suggest that WDR62 is the MCPH2 gene and have extended the phenotype beyond ordinary microcephaly.

\section{CDK5RAP2 (MCPH3)}

Bond et al. (2005) [44] identified mutations in cyclin dependant kinase 5 regulatory associated protein 2 (CDK5RAP2) gene at MCPH3 locus (MIM 608202). The gene contains 38 exons, genomic size is $191290 \mathrm{bp}$, with 5682 bp ORF and the deduced protein contains 1893 amino acids $[44,45,60]$. Multiple transcript variants exist for this gene on chromosome $9 q 33.2$, but the full-length nature of only two has been determined.

The CDK5RAP2 protein is predicted to contain one $\mathrm{N}$-terminal spindle associated domain and two potential chromosome segregation ATPase (SMC, structural maintenance of chromosomes) domains, which are known to play a role in the cohesion and condensation of chromosomes during mitosis [3]. CDK5RAP2 protein interacts with the gamma-tubulin ring complex (gTuRC) at its $\mathrm{N}$-terminus, with $\mathrm{CDK} 5$ regulatory subunit 1 (CDK5R1) at C-terminal interacting site and also contains several coiled-coil domains $[44,46]$.

Bond et al. (2005) [44] identified a homozygous base substitution in exon $4,243 \mathrm{~T} \rightarrow \mathrm{A}(\mathrm{S} 81 \mathrm{X})$ resulting in amino acid change, S81X, in one family from Pakistan. In the other Pakistani family they identified a homozygous mutation in intron 26 , IVS26-15A $\rightarrow$ G creating a new superior splice acceptor site, leading to the addition of four amino acids and a termination codon (E385fsX4). Hassan et al. (2007) [43] described recurrence of a previously known mutation (S81X) in $\mathrm{MCPH}$ family from Northern Pakistan and concluded that the exact nomenclature for this mutation was $246 \mathrm{~T}>\mathrm{A}$ (Y82X). They also concluded that recurrence of Y82X mutation in CDK5RAP2 gene in a family of Kashmiri origin may indicate confinement of this rare haplotype within Northern Pakistani population.

CDK5RAP2 is a centrosome-based protein, and its mRNA is widely expressed in human and in embryonal mouse tissue [44,61]. Nagase et al (2000) [62], have shown that gene expression of Cdk5rap2 in murine sections is highest in the brain and the spinal cord, particularly in the neuroepithelium of the frontal cortex early in neurogenesis. The mouse protein cdk5rap2 is localized throughout the pericentriolar material in all stages 
of cell cycle and associates with the $\gamma \operatorname{TuRC}(\gamma$ - tubulin ring complex) via a short conserved sequence present in several related proteins found in a range of organisms from fungi to mammals [63]. Perturbing human CDK5RAP2 protein function delocalized $\gamma$-tubulin from the centrosomes and inhibited centrosomal microtubule nucleation, thus leading to disorganization of interphase microtubule arrays and formation of anastral mitotic spindles [63].

Zhang et al (2009) [64] recently demonstrated that CDK5RAP2 is required for spindle checkpoint regulation. They found that loss of its function leads to chromosome mis-segregation and reduced expression of spindle checkpoint proteins, via interaction with their promoters and transcription regulation in HeLa cells. Lucas and Ruff (2007) [65], have found centrosome dysfunction; centrosome 'rocketing' within the cells due to loss of connection between centrosomes and pericentriolar matrix in human CDK5RAP2 ortholog, 'centrosomin,' deficient Drosophila embryos (cnn-/-). Only subtle defects of asymmetric divisions in 'centrosomin,' deficient Drosophila embryos (cnn-/-) were observed, and brains were reportedly of normal size. Previously, Terada et al (2003) [66] provided the evidence about the interaction of Drosophila orhtholog of CDK5RAP2, centrosomin $(c n n)$, with $\gamma$-tubulin ring complexes within the centrosome, which is responsible for the production of microtubules. Thus, CDK5RAP2 may affect neurogenic mitosis by affecting the accessibility of the microtubules that are required to assemble the mitotic spindles.

\section{CEP152 (MCPH4)}

Guernsey et al (2010) [67] have recently discovered both homozygous and heterozygous mutations in CEP152 gene located with in MCPH4 linkage interval at chromosome $15 \mathrm{q} 21.1$ in two Canadian families with $\mathrm{MCPH}$ using SNP-based genome scan. Human CEP152 gene, which is the putative mammalian ortholog of Drosophila asterless (asl), spans 72835 bp with protein product of $152 \mathrm{kDa}$ and 1710 amino acids for largest transcript variant [46].

Previously, Blachon et al (2008) [68] have demonstrated that Asl (ortholog of CEP152 in Drosophila) is a conserved gene required for ciliogenesis; is involved in the initiation of centriole duplication and that it is dispensable for pericentriolar material (PCM) recruitment in meiosis in $\mathrm{MC}$ centrioles (Mother Centrioles). They were successful to show that asl is essential for centriole formation in brain cells and spermatocytes. The generated mechanosensory mutant D, mecD, (a mutant allele of $a s l$ ) exhibited all of the characteristics of a ciliary defect with a severe phenotype of uncoordination and nonmotile sperm tails and also confirmed the absence of cilia by serial-section electron microscopy (EM) of the sensory neurons and the sperm tails.

However, in mice, Guernsey et al (2010) [67] were able to generate a cDNA clone product of the correct size spanning exons 21-24 of the mouse Cep152 ortholog by using RNA extracted from mouse brain tissue; cDNA could be readily detected in stage 12.5 and 14.5 embryonic brains. They have also used tools of bioinformatics to elaborate the pathogenic effect of homozygous mutation in CEP152 gene (Q265P) in two MCPH4 linked families [67].

\section{ASPM (MCPH5)}

Bond et al. (2002) [22] identified mutations in ASPM (Abnormal Spindle-like Microcephaly-Associated), a human ortholog of the Drosophila melanogaster 'abnormal spindle' gene (asp), which is essential for normal mitotic spindle function in embryonic neuroblast at MCPH5 locus. The gene spans 62567 bp with 10906 bp ORF [46]. The ASPM gene contains 28 exons and deduced protein contains 3477 amino acids, comprising of a putative microtubule-binding domain at its, Nterminal with ciliary function [69-71], a calponin-homology domain $(\mathrm{CH}), 81$ isoleucine-glutamine (IQ) motifs which act as calmodulin-binding domains $[22,69,70]$ and a carboxy terminal region with no identifiable domains [70,72]. The number of ASPM IQ domains is constant among diverse mammals, with the exception of some rodents and, are thought to be involved in increased cerebral cortical size in mammalian evolution [71,72].

Mutations in ASPM gene (discovered so far) are protein-truncating; they are distributed throughout the gene without any observed association of phenotypic severity with mutation position or type and are the most common cause of MCPH World-wide [11,16,17,19,22,73,74]. These mutations include single base-pair changes, deletions, duplications and intronic variants. Also, a significant number of the ASPM mutations have been in compound-heterozygous form $[9,16]$.

ASPM is expressed in the cerebral cortical ventricular zone and proliferative zones of the medial and lateral ganglionic eminences during neurogenesis [22]. Several alternatively spliced variants, encoding putative ASPM isoforms with different numbers of IQ motifs have been identified suggesting the existence of isoforms with potentially different functions [71]. Fish et al (2006) [75], revealed that Aspm (orthologue for mouse protein) protein localizes to spindle poles, and its siRNA mediated knockdown decreases proliferative symmetric divisions in developing neocortex of mouse. They have shown that ASPM maintains symmetrical cell divisions and is down-regulated with the switch from proliferative to neurogenic divisions. Also, it has been found that Nand C-termini of ASPM differentially localize within 
mitotic cells to either spindle poles or to midbodies, respectively [76]. In general, ASPM expression has been linked to proliferation and is highest in progenitor cells. Mouse Aspm is down regulated upon neurosphere differentiation, and knockdown of Aspm reduced both the self-renewal capacity and proliferation of neurospheres upon re-culture [1]. ASPM might also contribute to adult neurogenesis, as stimulating proliferation of neural precursors in adult rat hippocampus induced Aspm expression [77].

In some recent studies, expression of ASPM in cancer cells has been investigated. Aspm has been found downregulated in ionizing-radiation treated cells [78], and its down-regulation has shown to decrease Brca1 protein expression as well [79]. In another study, ASPM mRNA was found over-expressed in transformed human cell lines and tumors, and its increased expression was positively associated with proliferation of glioblastoma cells [80].

ASPM plays a role in mitotic spindle function including orientation of cleavage plane. The spindle apparatus dictates the plane of cell cleavage, which is critical in the choice between symmetric or asymmetric division $[4,81,82]$. Drosophila asp gene mutants were the first to be called as mini-brain. Gonzalez et al (1990) [83], described mitotic arrest in these flies with centrosome did not functioning correctly as microtubule organizing center. Drosophila asp gene is known to be essential for both the organization and binding together of microtubules at the spindle poles, the formation of the central mitotic spindle and to focus the poles of the mitotic spindles during mitosis and meiosis $[81,82]$. The mitotic spindle positioning was defective, along with the defects in cell cleavage plane positioning during asymmetric cell division and spermatogenesis.

Pulvers et al (2010) [84] generated two mutant mouse lines from gene trap cells to study the function of Aspm in the development of the cerebral cortex and elsewhere. They discovered that the mutations in Aspm reduce brain size in mice, similar in nature to, albeit with less severity than, human primary microcephaly. They concluded that possible origins of this difference in severity may lie in the difference in brain size itself. They also found that human ASPM transgene rescues the microcephaly phenotype but does not produce a gain of function in mice. They have demonstrated that mutations in Aspm reduce fertility in males and females mice but do not alter copulation frequency.

Given the known functions of Drosophila and mouse orthologs of ASPM, it is, therefore, proposed that mutations of $A S P M$ might reduce brain size by influencing mitotic spindle orientation, and reduce neural cell number through an effect on the ratio of asymmetric to symmetric cell divisions $[1,82]$.

\section{CENPJ/CPAP (MCPH6)}

Bond et al. (2005) [44] identified two mutations in Centromere-associated Protein J (CENPJ) gene in one Brazilian and two Pakistani families within a previously identified locus on human chromosome 13q12.2 [41]. The CENPJ gene (MIM 609279) spans 40672 bp with 5187 bp ORF [46]. It has 17 exons and deduced 1,338amino acid protein contains 5 coiled-coil domains, the most C-terminal of which includes a leucine zipper motif, several potential protein phosphorylation sites and a C-terminal domain containing 21 nonamer G-box repeats $[44,85]$. It also contains a 112 - amino acid long microtubule destabilizing motif PN2-3 [86] and two Cterminal 14-3-3 binding sites [87]. Wide expression of CENPJ is found with the highest expression in brain and spinal cord; primary expression has been localized to the neuroepithelium of the frontal cortex early in the neurogenesis [44].

Four mutations have been reported in this gene so far. Initially two mutations were reported in three families [44], including two families from Northern Pakistan having one mutation and other from Brazil with second mutation. Later, in a Pakistani family from Pashto language group, a deletion of four consecutive nucleotides (TCAG) was identified in exon 11 of CENPJ gene, leading to frameshift and premature termination codon 19 bp downstream in the same exon, predicted to add six amino acids downstream of the mutation [88]. More recently, a novel splicing mutation in CENPJ gene [89] has been observed in Seckel syndrome patients.

CENPJ is localized at the centrosome during mitosis and it is concentrated at the mitotic spindle poles during prometaphase and metaphase $[44,86]$. Recently, Cho et al, (2006) [90], have observed that depletion of CENPJ disrupts centrosome integrity, and cells lacking CPAP arrest in mitosis with multipolar spindles. In vitro evidence suggests that CENPJ might be able to inhibit microtubule nucleation and microtubules depolymerization [87].

It has been found that CENPJ depletion by the use of siRNA lead to an increase of multiple spindle poles, mitosis arrest and apoptosis. CENPJ interacts with the $\mathrm{N}$-terminal domain of the p65 subunit (RelA) of NFkappaB, a transcription factor important for various cellular events such as inflammation, immune response, proliferation and apoptosis [91].

Loss of the CENPJ orthologue dsas-4 in Drosophila leads to the loss of centrioles; although knockout flies survive until adulthood, their coordination is poor and viability is also low [92]. Mutant flies developed into morphologically normal adults without cilia or flagella and died shortly early in life [93]. In C. elegans, sas-4 is a centriolar protein that controls centrosome size (centrosomal organization) [94]. The role of sas-4 in 
centrosome duplication was further underlined by FRAP (fluorescence recovery after photo bleaching) studies demonstrating that sas- 4 was recruited to the centrosome once per cell cycle, at the onset of the organelle duplication cycle in the $S$ phase [95]. CENPJ is therefore a crucial regulator of centriole length during centriole biogenesis, possibly functioning in the correct recruitment of centriolar microtubules.

\section{7- STIL / SIL (MCPH7)}

Seventh locus for primary microcephaly (MCPH7, MIM 612703) was mapped by Kumar et al, 2009 [42] in families with primary microcephaly to a region of 8.39 $\mathrm{Mb}$ on chromosome 1p33-p32.3. Sequence analysis of STIL (SCL/TAL1-Interrupting Locus) gene that codes for a pericentriolar and centrosomal protein revealed 3 different homozygous protein truncating mutations in affected members of 5 Indian families linked to MCPH7. The STIL gene spans 63018 bp with 5225 bp ORF [45]. It contains 20 exons and 1287 residues in full-length protein. STIL is a cytosolic protein of 150 $\mathrm{kDa}$ whose function is not fully understood and which lacks homology to any known protein families or motifs [45]. The human full length 1287 amino acid protein contains a putative nuclear localization signal and a Cterminal domain similar to that of TGF-beta [96].

STIL is expressed throughout the cytosol with increased expression in the perinuclear region that likely plays a role in mitotic entry (cell cycle progression G2$\mathrm{M})$, apoptosis control and centrosome function [42]. Karkera et al (2002) [96], found that the human STIL protein contains a putative nuclear localization signal and a cysteine-terminal domain similar to the C-terminal domain of TGF-beta. It was found by Aplan et al (1990) [97], that genomic rearrangements, containing the STIL gene, have been associated with T-cell acute lymphoblastic leukemia (ALL). STIL is phosphorylated in mitosis and then interacts with PIN1 (peptidyl prolyl isomerase) which in turn regulates a subset of mitotic phospoproteins [98]. STIL is an early response gene that is ubiquitously expressed in proliferating cells and during early embryonic development $[98,99]$.

Data obtained from zebrafish indicate that stil may not only play a role in centrosome function/duplication, but also in organizing the mitotic spindle. Loss-of-function mutation in zebrafish sil has an embryonic lethal defect [98]. While homozygous sil knockout mice $\left(\mathrm{Sil}^{-/-}\right)$display several developmental abnormalities around embryonal day (E) 7.5-8.5 and die after E10.5 [100]. They described the phenotype of mutant mice showing reduced size, limited developmental progress, midline neural tube defects, abnormal left-right development, increased rates of apoptosis, decreased rates of proliferation, abnormal expression of several important genes including "lefty 2 " and "nodal". Also the mutants were found to be embryonal lethal.

\section{Mutation spectrum of MCPH Genes in Pakistani Population}

Pakistani population constitutes of at least 18 ethnic groups and speaks more than 60 languages [101,102]. Mostly, it belongs to Indo-European speakers from India, although Hazaras, Pathans, Balti, Brusho and Balouch language groups are found to carry West-Asian, Arabian, and European ancestry $[101,103,104]$. Due to high rate of consanguinity ( $61 \%)$ and large family size [34], Pakistani population has proved to be rich for genetic linkage studies.

Northern Pakistan is a wide geographical region that harbors people from different language groups e.g. Kashmiri, Shina, Balti, Pashto, Hindko etc. All these groups tend to marry within their close relatives. As a large number of Pakistani MCPH families belong to this region, there is an ample need to detect localization of $\mathrm{MCPH}$ gene mutations in specific language groups within this area. This will certainly help in prenatal diagnosis of $\mathrm{MCPH}$ and will enhance our knowledge about the dispersion of $\mathrm{MCPH}$ alleles in different language groups within Pakistani population.

A total of about 95 families have been reported with mutations in any of MCPH genes from Pakistan, most of them belonging to Northern Pakistan. Except one recently discovered locus from India (MCPH7), all other $\mathrm{MCPH}$ loci have been reported in Pakistani families (Tables 4, 5 and 6).

ASPM gene mutations have been found in 83 families with 2 families having compound heterozygous mutations. Language group is not mentioned for a large number of these families (Northern Pakistan is not a single language group). Two mutations 3978G-A and 8508delGA were most common, segregating in 18 and 4 families respectively (Table 5). The mutation 3978G-A has segregated mostly in Pashto language group. Although, Muhammad et al, (2009) [16] and Kousar et al, (2010) [105] have reported this mutation in families from Pakistan, but not clearly mentioned the language group.

CDK5RAP2 gene mutations have been found in three Pakistani families so far, and they are exclusive to Pakistan. One mutation (IVS26-15A-G) was observed in one family while other mutation (Y82X) was present in two families. All these families belong to Northern Pakistan but for only one family, language group has been mentioned.

Two mutations have been found in CENPJ gene segregating in three Pakistani families. One mutation 17delC was present in affected individuals from two families belonging to Northern Pakistan. The second mutation 
Table 4 An account of Pakistani families linked to different MCPH loci and a comparison with other populations

\begin{tabular}{|c|c|c|c|}
\hline Locus/Gene & $\begin{array}{l}\text { No. of Pakistani } \\
\text { Families linked * }\end{array}$ & $\begin{array}{l}\text { No. of Mutations Reported } \\
\text { in Pakistani Families }\end{array}$ & No. of Families linked worldwide* \\
\hline $\begin{array}{l}\text { MCPH1 } \\
\text { (Microcephalin) }\end{array}$ & $2(1.39 \%)$ & 2 & 8 Iranian families, 1 Caucasian family \\
\hline MCPH2 (WDR62) & $2(1.39 \%)$ & 1 & 3 Iranian families, 11 Turkish families, 1 Mexican family, 1 Arab family, \\
\hline $\begin{array}{l}\text { MCPH3 } \\
\text { (CDK5RAP2) }\end{array}$ & $3(2.09 \%)$ & 2 & No family reported outside Pakistan \\
\hline MCPH4 (CEP152) & $2(1.39 \%)$ & 0 & 3 Canadian families and 1 Arab Family \\
\hline MCPH5 (ASPM) & $83(58.04 \%)$ & 79 & $\begin{array}{l}13 \text { Iranian Families, } 12 \text { Arab families, } 8 \text { Indian families, about } 22 \text { European } \\
\text { families, } 5 \text { african families, and many sporadic patients }\end{array}$ \\
\hline MCPH6 (CENPJ) & $3(2.09 \%)$ & 3 & 5 Iranian Families, 1 Brazilian Family \\
\hline \multirow[t]{2}{*}{ MCPH7 (STIL) } & $0(0 \%)$ & 0 & 3 Indian Families, 2 Iranian Families \\
\hline & \multicolumn{3}{|c|}{48 Pakistani families (33.56\%), } \\
\hline $\begin{array}{l}\text { Families Not } \\
\text { Linked to any } \\
\text { locus }\end{array}$ & \multicolumn{3}{|c|}{ About 120 families from different World Populations have reported to be unlinked to known MCPH loci including 81 from Iran } \\
\hline
\end{tabular}

Total Families

143 Pakistani families and about 200 families with MCPH World wide have been screened so far

Screened so far

*- Number of families has been calculated from published data. Research groups working on genetics of MCPH may have more families in their labs.

(3243delTCAGa) was found segregated in a Pakistani family from Pashto language group.

In one Pakistani family linked to $\mathrm{MCPH} 2$ locus Nicholas et al, 2010 [27] have detected a missense mutation c.3232G-A (Ala1078Thr) in exon 27 of the WDR62 gene (Table 6).This family belongs to Sindhi language group of southern Pakistan. Previously the locus was reported in Pakistani families only but the mutations in WDR62 gene have been found in microcephaly patients from other countries as well $[21,26,27]$.

\section{Evolution of MCPH Genes and Mammalian Brain Size}

MCPH significantly affects the ratio of brain size to body size. Brain size of the affected individuals is comparable to that of early hominids, chimpanzee or gorilla $[22,25]$. Almost all genes involve in $\mathrm{MCPH}$ seem to play a role in mitosis of neuronal precursors. The acceleration of protein evolution has been observed to be most prominent in the lineage leading from ancestral primates to human, therefore, it is concluded that the phenotypic evolution of the human nervous system has a salient molecular correlate, i.e., accelerated evolution of the underlying genes, particularly those linked to nervous system development $[106,107]$. Many investigators tried to find out evidence for adaptive changes in these genes and also studied the correlation of these changes with change in relative brain size during evolution and cognitive abilities that evolved us as human.

Genetic variants of $A S P M$ and $M C P H 1$ genes in human have been shown to arise nearly about 5,800 years and 36,000 years ago and have since swept to high frequency under strong positive selection [108-110]. Identification of these remarkably young-aged, positively selected variants suggested that the human brain is still undergoing rapid adaptive evolution. However, it has been suggested that certain developed models of human history including both population growth and spatial structure could generate the observed pattern of ASPM and $M C P H 1$ haplotypes without selection [111]. Later, it was proposed that these variations are not unusual, do not support selection and ongoing adaptive evolution of $A S P M$ and $M C P H 1$ is not explained by increased intelligence [112-114]. Molecular evolutionary studies on CDK5RAP2 and CENPJ also revealed accelerated rates of non-synonymous substitutions within respective functional domains of the genes, in lineage leading to Homo sapiens that are likely the result of positive selection [60]. More recently, it has been observed that a common SNP of MCPH1 (previously not described) is associated with cranial volume variation in Chinese population without any detectable selection signal, suggesting that the brain volume variation in human populations is likely neutral or under very weak selection in recent human history [115].

The claim that distribution of $A S P M-D$ allele and $M C P H-D$ allele is the result of positive selection has been challenged by several groups, but arguably remains the best explanation. Also, it has been observed by researchers that the predicted ASPM proteins encode systematically larger numbers of repeated 'IQ' domains between flies, mice, and humans, with the predominant difference between Aspm and ASPM being a single large insertion coding for IQ domains $[4,75]$. But on the 
Table 5 ASPM gene mutations in MCPH families from Pakistan

\begin{tabular}{|c|c|c|c|c|}
\hline Mutation & Language Group & State of Mutation & Present in No. of families from Pakistan & Reference \\
\hline $349 C-T$ & Northern Pakistani & homozygous & One & [22] \\
\hline 719delCT & Northern Pakistani & homozygous & One & {$[74]$} \\
\hline 1258delTCTCAAT & Northern Pakistani & homozygous & Two & {$[22,74]$} \\
\hline 9190C-T & Northern Pakistani & homozygous & One & {$[22]$} \\
\hline 2936+5G-T (intronic) & Northern Pakistani & homozygous & One & [74] \\
\hline 1990C-T & Northern Pakistani & homozygous & One & {$[74]$} \\
\hline 8508delGA & Sindi, Northern Pakistani & homozygous & Four & {$[16,17,19,74]$} \\
\hline 3082G-A & Northern Pakistani & homozygous & One & [74] \\
\hline 4581 delA & Northern Pakistani & homozygous & One & [74] \\
\hline $4795 C-T$ & Northern Pakistani & homozygous & One & [74] \\
\hline $7895 \mathrm{C}-\mathrm{T}$ & Northern Pakistani & homozygous & One & [74] \\
\hline 9159delA & Northern Pakistani & homozygous & Three & {$[22,74,105]$} \\
\hline 9557C-G & Hindko & homozygous & Three & {$[11,74]$} \\
\hline 9984+1G-T (intronic) & Northern Pakistani & homozygous & One & {$[74]$} \\
\hline 3663delG & Northern Pakistani & homozygous & Two & [74] \\
\hline 1002delA & Pakistani & homozygous & One & [16] \\
\hline 2938C-T & Pakistani & homozygous & One & [16] \\
\hline $3055 C-T$ & Pakistani & homozygous & One & [16] \\
\hline 7894C-T & Pakistani/heterozygous & Homozygous & Two & [16] \\
\hline 3477delCGCTA & Pakistani & Homozygous & One & [16] \\
\hline 6732delA & Pakistani & Homozygous & One & [16] \\
\hline $8668 C-\mathrm{T}$ & Pakistani & Homozygous & One & {$[16]$} \\
\hline 3978G-A & Pashto.... & Heterozygous/homozygous & Eighteen & {$[11,16,17,105]$} \\
\hline 9319C-T & Pakistani & heterozygous & One & [16] \\
\hline 9492T-G & Pakistani & homozygous & Three & {$[16,105]$} \\
\hline $9595 \mathrm{~A}-\mathrm{T}$ & Pakistani & homozygous & One & [16] \\
\hline 9677insG & Pakistani & homozygous & One & [16] \\
\hline 9697C-T & Pakistani & homozygous & One & [16] \\
\hline 1260delTCAAGTC & Saraiki & homozygous & Two & {$[11,105]$} \\
\hline 3188T-G & Pakistani & homozygous & One & [19] \\
\hline 4855delTA & Pakistani & homozygous & One & [19] \\
\hline 5136C-A & Sindhi & homozygous & One & [17] \\
\hline 5149delA & Saraiki & homozygous & One & [17] \\
\hline 6335delAT & Pakistani & homozygous & One & {$[24]$} \\
\hline 7761T-G & Pakistani & homozygous & Two & {$[19,22]$} \\
\hline 7782delGA & Pakistani & homozygous & One & [19] \\
\hline 8378delT & Pakistani & homozygous & More than one & [19] \\
\hline 9118insCATT & Punjabi & homozygous & One & {$[11]$} \\
\hline 9238A-T & Punjabi & homozygous & Two & {$[11,19]$} \\
\hline 9681delA & Pakistani & homozygous & One & [19] \\
\hline 9730C-T & Kashmiri & homozygous & One & [17] \\
\hline 9745delCT & Pakistani & homozygous & One & [19] \\
\hline 9789T-A & Pakistani & homozygous & One & [19] \\
\hline 10059C-A & Saraiki & homozygous & One & [17] \\
\hline 9539A-C & Sindi & homozygous & One & [11] \\
\hline 2101C-T & Pakistani & homozygous & One & [105] \\
\hline 6686delGAAA & Pakistani & homozygous & Two & {$[8,105]$} \\
\hline 77delG & Pakistani & homozygous & Two & {$[8,105]$} \\
\hline
\end{tabular}


Table 6 MCPH1, WDR62, CDK5RAP2, and CENPJ mutations in MCPH families from Pakistan

\begin{tabular}{lccccc}
\hline Gene Symbol & Mutation & $\begin{array}{c}\text { Language } \\
\text { Group }\end{array}$ & $\begin{array}{c}\text { State of } \\
\text { Mutation }\end{array}$ & Present in No. of families from Pakistan & Reference \\
\hline MCPH1 & 74C-G & Northern Pakistani & Homozygous & Two & One \\
WDR62 & $3232 \mathrm{G}-\mathrm{A}$ & Sindhi & Homozygous & Two & {$[27]$} \\
& $246 \mathrm{~T}-\mathrm{A}$ & Kashmiri & Homozygous & One & {$[43,44]$} \\
CDK5RAP2 & IVS26-15A-G & Northern Pakistani & Homozygous & Two & {$[44]$} \\
& 17 delC & Northern Pakistani & Homozygous & One & {$[44]$} \\
CENPJ & 3243delTCAG & Pushto & Homozygous & & {$[88]$} \\
\hline
\end{tabular}

other hand, the expansion of IQ repeats has been observed in other non-primates mammalians [116], and raises the question of the physiological process which really benefits from the selection pressure.

It is important to mention that the derived haplogroups of $A S P M$ and $M C P H 1$ were apparently not found to be involved in variations in brain size [117], intelligence [112], head circumference, general mental ability, social intelligence $[113,114]$ or the incidence of schizophrenia [118]. It has been proposed by Dediu and Ladd (2007) [119] that effects of derived haplogroups of $M C P H 1$ and $A S P M$ are involved in subtle differences in the organization of the cerebral cortex, with cognitive consequences including linguistic biases in the processing and acquisition of linguistic tone.

More recently, Montgomery et al (2011) [120] have analyzed the molecular evolution of four genes associated with microcephaly (ASPM, CDK5RAP2, CENPJ, MCPH1) across 21 species representing all major clades of anthropoid primates and have found that contrary to prevailing assumptions, positive selection was not limited to or intensified along the lineage leading to humans. Out of four genes tested, they found positive relationships only between CDK5RAP2 and ASPM and neonatal brain mass and somewhat weaker relationships between these genes and adult brain size. The stronger association of ASPM and $C D K 5 R A P 2$ evolution with neonatal brain size than with adult brain size is consistent with these loci having a direct effect on prenatal neuronal proliferation.

The results shown by Montgomery et al (2011) [120] have suggested that primate brain size may have at least a partially conserved genetic basis, and have contradicted previous studies that linked adaptive evolution of ASPM to changes in relative cortex size. Their findings about pervasive positive selection in coding regions of two widely expressed loci in relation to a complex, quantitative developmental phenotype have provided a notable counterexample to the commonly asserted hypothesis that cis-regulatory regions play a dominant role in phenotypic evolution.

\section{Conclusion}

One of the most obvious structural characteristics of the human brain, when compared with that of other mammals, is its large size. Cognitive abilities decrease with a significant decrease in brain size and most striking example of it is Autosomal Recessive Primary Microcephaly $(\mathrm{MCPH})$, in which brain size reduces to one third of its original volume with a significant cognitive decline. The $\mathrm{MCPH}$ proteins are involved in different molecular pathways including DNA damage response signaling, cell division, proper spindle orientation, microtubule dynamics, cell cycle regulation etc. Recent functional studies confirm the presence of $\mathrm{MCPH}$ proteins at centrosome for at least part of cell cycle. Therefore, one may conclude that centrosome is the final integration point for many regulatory pathways affecting prenatal neurogenesis in mammals. The ASPM gene at MCPH5 locus and WDR62 at MCPH2 locus are the most common cause of $\mathrm{MCPH}$ respectively. Recent successful generation of mammalian models for $\mathrm{MCPH}$ has open up horizons for researchers to add more knowledge regarding the etiology and pathophysiology of MCPH. Better genotyping, neuroimaging and neuro-physiological testing, along with constitution of genetically homogeneous groups of patients, would help in establishing exact genotypephenotype correlation. Mutation screening in $\mathrm{MCPH}$ families from Pakistan along with the information about ethnic origin/language group is need of the time, because this population is the most affected group. It will help in genetic counseling and prenatal diagnosis for $\mathrm{MCPH}$ in Pakistan, and thus in turn may help reducing the incidence of $\mathrm{MCPH}$ from this highly consanguineous population.

\section{Acknowledgements}

$\mathrm{MJH}$ is partially funded by Pakistan Science Foundation (PSF) and Higher Education Commission (HEC), Islamabad, Pakistan. We wish to thank our students and colleagues for their questions and comments that motivate us to write this review. We also thank our staff/students for availability of tea/ coffee throughout the preparation of this manuscript.

\section{Author details}

'Department of Human Genetics and Molecular Biology, University of Health Sciences, Khayaban-e-Jamia Punjab, Lahore, 54600, Pakistan. ${ }^{2}$ Department of Biochemistry, Faculty of Biological Sciences, Quaid-i-Azam University,

Islamabad, 44000, Pakistan. ${ }^{3}$ Department of Biochemistry, University of Health Sciences, Khayaban-e-Jamia Punjab, Lahore, 54600, Pakistan. 


\section{Authors' contributions}

All authors contributed equally in this work in terms of literature search, systematization and writing. All authors read and approve the final submitted version of this manuscript

\section{Competing interests}

The authors declare that they have no competing interests.

Received: 22 October 2010 Accepted: 13 June 2011

Published: 13 June 2011

\section{References}

1. Thornton GK, Woods CG: Primary microcephaly: do all roads lead to Rome? Trends Genet 2009, 25:501-510.

2. Mochida GH: Genetics and biology of microcephaly and lissencephaly. Semin Pediatr Neurol 2009, 16:120-126.

3. Cox J, Jackson AP, Bond J, Woods CG: What primary microcephaly can tell us about brain growth? Trends Mol Med 2006, 12:358-366.

4. Woods CG, Bond J, Enard W: Autosomal recessive primary microcephaly (MCPH): a review of clinical, molecular, and evolutionary findings. Am $J$ Hum Genet 2005, 76:717-728.

5. Mochida GH, Walsh CA: Genetic basis of developmental malformations of the cerebral cortex. Arch Neurol 2004, 61:637-640.

6. Mochida GH, Walsh CA: Molecular genetics of human microcephaly. Curr Opin Neurol 2001, 14:151-156

7. McCreary BD, Rossiter JP, Robertson DM: Recessive (true) microcephaly: a case report with neuropathological observations. J Intellect Disabil Res 1996, 40:66-70.

8. Passemard S, Titomanlio L, Elmaleh M, Afenjar A, Alessandri JL, Andria G, de Villemeur TB, Boespflug-Tanguy O, Burglen L, Del Giudice E, Guimiot F, Hyon C, Isidor B, Mégarbané A, Moog U, Odent S, Hernandez K, Pouvreau N, Scala I, Schaer M, Gressens P, Gerard B, Verloes A: Expanding the clinical and neuroradiologic phenotype of primary microcephaly due to ASPM mutations. Neurology 2009, 73:962-969.

9. Saadi A, Borck G, Boddaert N, Chekkour MC, Imessaoudene B, Munnich A, Colleaux L, Chaouch M: Compound heterozygous ASPM mutations associated with microcephaly and simplified cortical gyration in a consanguineous Algerian family. Eur J Med Genet 2009, 52:180-184.

10. Desir J, Abramowicz M, Tunca Y: Novel mutations in prenatal diagnosis of primary microcephaly. Prenat Diagn 2006, 26:989-993.

11. Gul A, Hassan MJ, Mahmood S, Chen W, Rahmani S, Naseer MI, Dellefave L, Muhammad N, Rafiq MA, Ansar M, Chishti MS, Ali G, Siddique T, Ahmad W: Genetic studies of autosomal recessive primary microcephaly in 33 Pakistani families: Novel sequence variants in ASPM gene. Neurogenetics 2006, 7:105-110.

12. Roberts E, Hampshire DJ, Pattison L, Springell K, Jafri H, Corry P, Mannon J, Rashid Y, Crow Y, Bond J, Woods CG: Autosomal recessive primary microcephaly: an analysis of locus heterogeneity and phenotypic variation. J Med Genet 2002, 39:718-721.

13. Nellhaus G: Head circumference from birth to eighteen years: practical composite of international and interracial graphs. Pediatrics 1968, 4:106-114.

14. Abuelo D: Microcephaly syndromes. Semin Pediatr Neurol 2007, 14:118-127.

15. Teebi AS, Al-Awadi SA, White AG: Autosomal recessive nonsyndromal microcephaly with normal intelligence. Am J Med Genet A 1987, 26:355-359.

16. Muhammad F, Mahmood Baig S, Hansen L, Sajid Hussain M, Anjum Inayat I, Aslam M, Anver Qureshi J, Toilat M, Kirst E, Wajid M, Nürnberg P, Eiberg H, Tommerup N, Kjaer KW: Compound heterozygous ASPM mutations in Pakistani MCPH families. Am J Med Genet A 2009, 149A:926-930.

17. Gul A, Tariq M, Khan MN, Hassan MJ, Ali G, Ahmad W: Novel proteintruncating mutations in the ASPM gene in families with autosomal recessive primary microcephaly. J Neurogenet 2007, 21:153-163.

18. Shen J, Eyaid W, Mochida GH, Al-Moayyad F, Bodell A, Woods CG, Walsh CA: ASPM mutations identified in patients with primary microcephaly and seizures. J Med Genet 2005, 42:725-729.

19. Nicholas AK, Swanson EA, Cox JJ, Karbani G, Malik S, Springell K, Hampshire D, Ahmed M, Bond J, Di Benedetto D, Fichera M, Romano C, Dobyns WB, Woods CG: The molecular landscape of ASPM mutations in primary microcephaly. J Med Genet 2009, 46:249-253.
20. Kumar A, Blanton SH, Babu M, Markandaya M, Girimaji SC: Genetic analysis of primary microcephaly in Indian families: novel ASPM mutations. Clin Genet 2004, 66:341-348.

21. Yu TW, Mochida GH, Tischfield DJ, Sgaier SK, Flores-Sarnat L, Sergi CM, Topçu M, McDonald MT, Barry BJ, Felie JM, Sunu C, Dobyns WB, Folkerth RD, Barkovich AJ, Walsh CA: Mutations in WDR62, encoding a centrosome-associated protein, cause microcephaly with simplified gyri and abnormal cortical architecture. Nat Genet 2010, 42:1015-1020.

22. Bond J, Roberts E, Mochida GH, Hampshire DJ, Scott S, Askham JM, Springell K, Mahadevan M, Crow YJ, Walsh CA, Woods CG: ASPM is a major determinant of cerebral cortical size. Nat Genet 2002, 32:316-320.

23. Trimborn M, Richter R, Sternberg N, Gavvovidis I, Schindler D, Jackson AP, Prott EC, Sperling K, Gillessen-Kaesbach G, Neitzel H: The first missense alteration in the MCPH1 gene causes autosomal recessive microcephaly with an extremely mild cellular and clinical phenotype. Hum Mutat 2005, 26:496.

24. Trimborn M, Bell SM, Felix C, Rashid Y, Jafri H, Griffiths PD, Neumann LM, Krebs A, Reis A, Sperling K, Neitzel H, Jackson AP: Mutations in microcephalin cause aberrant regulation of chromosome condensation. Am J Hum Genet 2004, 75:261-266.

25. Jackson AP, Eastwood H, Bell SM, Adu J, Toomes C, Carr IM, Roberts E, Hampshire DJ, Crow YJ, Mighell AJ, Karbani G, Jafri H, Rashid Y, Mueller RF, Markham AF, Woods CG: Identification of microcephalin, a protein implicated in determining the size of the human brain. Am J Hum Genet 2002, 71:136-142.

26. Bilgüvar K, Oztürk AK, Louvi A, Kwan KY, Choi M, Tatli B, Yalnizoğlu D, Tüysüz B, Cağlayan AO, Gökben S, Kaymakçalan H, Barak T, Bakircioğlu M, Yasuno K, Ho W, Sanders S, Zhu Y, Yilmaz S, Dinçer A, Johnson MH, Bronen RA, Koçer N, Per H, Mane S, Pamir MN, Yalçinkaya C, Kumandaș S, Topçu M, Ozmen M, Sestan N, Lifton RP, State MW, Günel M: Whole-exome sequencing identifies recessive WDR62 mutations in severe brain malformations. Nature 2010, 467:207-210.

27. Nicholas AK, Khurshid M, Désir J, Carvalho OP, Cox JJ, Thornton G, Kausar R, Ansar M, Ahmad W, Verloes A, Passemard S, Misson JP, Lindsay S, Gergely F, Dobyns WB, Roberts E, Abramowicz M, Woods CG: WDR62 is associated with the spindle pole and is mutated in human microcephaly. Nat Genet 2010, 42:1010-1014.

28. Desir J, Cassart M, David P, Van Bogaert P, Abramowicz M: Primary microcephaly with $A S P M$ mutation shows simplified cortical gyration with antero-posterior gradient pre- and post-natally. Am J Med Genet $A$ 2008, 146A:1439-1443

29. Vermeulen RJ, Wilke $M$, Horber V, Krägeloh-Mann I: Microcephaly with simplified gyral pattern: MRI classification. Neurology 2010, 74:386-391.

30. International Clearinghouse for Birth Defects Surveillance and Research, 2006 report. [http://www.icbdsr.org/]

31. Tolmie JL, McNay M, Stephenson JB, Doyle D, Connor JM: Microcephaly: genetic counselling and antenatal diagnosis after the birth of an affected child. Am J Med Genet 1987, 27:583-594.

32. Van den Bosch J: Microcephaly in the Netherlands: a clinical and genetical study. Ann Hum Genet 1959, 23:91-116.

33. Komai T, Kishimoto K, Ozaki Y: Genetic study of microcephaly based on Japanese material. Am J Hum Genet 1955, 7:51-65.

34. Hussain R, Bittles AH: The prevalence and demographic characteristics of consanquineous marriages in Pakistan. J Biosoc Sci 1998, 30:261-275.

35. Jackson AP, McHale DP, Campbell DA, Jafri H, Rashid Y, Mannan J, Karbani G, Corry P, Levene MI, Mueller RF, Markham AF, Lench NJ, Woods CG: Primary autosomal recessive microcephaly $(\mathrm{MCPH} 1)$ maps to chromosome 8p22-pter. Am J Hum Genet 1998, 63:541-546.

36. Roberts E, Jackson AP, Carradice AC, Deeble VJ, Mannan J, Rashid Y, Jafri $H$, McHale DP, Markham AF, Lench NJ, Woods CG: The second locus for autosomal recessive primary microcephaly $(\mathrm{MCPH} 2)$ maps to chromosome 19q131-132. Eur J Hum Genet 1999, 7:815-820.

37. Jamieson CR, Govaerts C, Abramowicz MJ: Primary autosomal recessive microcephaly: homozygosity mapping of MCPH4 to chromosome 15. Am J Hum Genet 1999, 65:1465-1469.

38. Jamieson CR, Fryns JP, Jacobs J, Matthijs G, Abramowicz MJ: Primary autosomal recessive microcephaly MCPH5 maps to $1 \mathrm{q} 25-1 \mathrm{q} 32$. Am J Hum Genet 2000, 67:1575-1577.

39. Moynihan L, Jackson AP, Roberts E, Karbani G, Lewis I, Corry P, Turner G, Mueller RF, Lench NJ, Woods CG: A third locus for primary autosomal 
recessive microcephaly maps to chromosome 9q34. Am J Hum Genet 2000, 66:724-777.

40. Pattison L, Crow YJ, Deeble VJ, Jackson AP, Jafri H, Rashid Y, Roberts E, Woods CG: A fifth locus for primary autosomal recessive microcephaly maps to chromosome 1q31. Am J Hum Genet 2000, 67:1578-1580.

41. Leal GF, Roberts E, Silva EO, Costa SM, Hampshire DJ, Woods CG: A novel locus for autosomal recessive primary microcephaly (MCPH6) maps to 13q122. J Med Genet 2003, 40:540-542.

42. Kumar A, Girimaji SC, Duvvari MR, Blanton SH: Mutations in STIL, encoding a pericentriolar and centrosomal protein, cause primary microcephaly. Am J Hum Genet 2009, 84:286-290.

43. Hassan MJ, Khurshid M, Azeem Z, John P, Ali G, Chishti MS, Ahmad W: Previously described sequence variant in CDK5RAP2 gene in a Pakistani family with autosomal recessive primary microcephaly. BMC Med Genet 2007, 8:58-64

44. Bond J, Roberts E, Springell K, Lizarraga SB, Scott S, Higgins J, Hampshire DJ, Morrison EE, Leal GF, Silva EO, Costa SM, Baralle D, Raponi M, Karbani G, Rashid Y, Jafri H, Bennett C, Corry P, Walsh CA, Woods CG: A centrosomal mechanism involving CDK5RAP2 and CENPJ controls brain size. Nat Genet 2005, 37:353-355.

45. Kaindl AM, Passemard S, Kumar P, Kraemer N, Issa L, Zwirner A, Gerard B, Verloes A, Mani S, Gressens P: Many roads lead to primary autosomal recessive microcephaly. Prog Neurobiol 2010, 90:363-383.

46. Human Genome Browser website, 2010. [http://genome.ucsc.edu/cgi-bin/ hgGateway].

47. Farooq M, Baig S, Tommerup N, Kjaer KW: Craniosynostosis-microcephaly with chromosomal breakage and other abnormalities is caused by a truncating $\mathrm{MCPH} 1$ mutation and is allelic to premature chromosomal condensation syndrome and primary autosomal recessive microcephaly type 1. Am J Med Genet A 2010, 152A:495-497.

48. Garshasbi M, Motazacker MM, Kahrizi K, Behjati F, Abedini SS, Nieh SE, Firouzabadi SG, Becker C, Rüschendorf F, Nürnberg P, Tzschach A, Vazifehmand R, Erdogan F, Ullmann R, Lenzner S, Kuss AW, Ropers HH, Najmabadi H: SNP array-based homozygosity mapping reveals $M C P H 1$ deletion in family with autosomal recessive mental retardation and mild microcephaly. Hum Genet 2010, 118:708-715.

49. Ponting C, Jackson AP: Evolution of primary microcephaly genes and the enlargement of primate brains. Curr Opin Genet Dev 2005, 15:241-248.

50. Xu X, Lee J, Stern DF: Microcephalin is a DNA damage response protein involved in regulation of CHK1 and BRCA1. J Biol Chem 2004, 279:34091-34094.

51. Neitzel H, Neumann LM, Schindler D, Wirges A, Tönnies H, Trimborn M, Krebsova A, Richter R, Sperling K: Premature chromosome condensation in humans associated with microcephaly and mental retardation: a novel autosomal recessive condition. Am J Hum Genet 2002, 70:1015-1022.

52. O'Driscoll M, Jackson AP, Jeggo PA: Microcephalin: a causal link between impaired damage response signalling and microcephaly. Cell Cycle 2006, 5:2339-2344

53. Trimborn M, Schindler D, Neitzel H, Hirano T: Misregulated chromosome condensation in $\mathrm{MCPH} 1$ primary microcephaly is mediated by condensin II. Cell Cycle 2006, 5:322-326.

54. Wood JL, Singh N, Mer G, Chen J: MCPH1 functions in an H2AXdependent but MDC1-independent pathway in response to DNA damage. J Biol Chem 2007, 282:35416-35423.

55. Alderton GK, Galbiati L, Griffith E, Surinya KH, Neitzel H, Jackson AP, Jeggo PA, O'Driscoll M: Regulation of mitotic entry by microcephalin and its overlap with ATR signalling. Nat Cell Biol 2006, 8:725-733.

56. Brunk K, Vernay B, Griffith E, Reynolds NL, Strutt D, Ingham PW, Jackson AP: Microcephalin coordinates mitosis in the syncytial Drosophila embryo. $J$ Cell Sci 2007, 120:3578-3588.

57. Rickmyre JL, Dasgupta S, Ooi DL, Keel J, Lee E, Kirschner MW, Waddell S, Lee LA: The Drosophila homolog of MCPH1, a human microcephaly gene, is required for genomic stability in the early embryo. $J$ Cell Sci 2007, 120:3565-3577.

58. Trimborn $\mathrm{M}$, Ghani $\mathrm{M}$, Walther DJ, Dopatka M, Dutrannoy V, Busche A, Meyer F, Nowak S, Nowak J, Zabel C, Klose J, Esquitino V, Garshasbi M, Kuss AW, Ropers HH, Mueller S, Poehlmann C, Gavvovidis I, Schindler D, Sperling K, Neitzel H: Establishment of a mouse model with misregulated chromosome condensation due to defective Mcph1 function. PLOS One 2010, 5(2):e9242.
59. Liang Y, Gao H, Lin SY, Peng G, Huang X, Zhang P, Goss JA, Brunicardi FC, Multani AS, Chang S, Li K: BRIT1/MCPH1 is essential for mitotic and meiotic recombination DNA repair and maintaining genomic stability in mice. PLoS Genet 2010, 6(1):e1000826.

60. Evans PD, Vallender EJ, Lahn BT: Molecular evolution of the brain size regulator genes CDK5RAP2 and CENPJ. Gene 2006, 375:75-79.

61. Ching YP, Qi Z, Wang JH: Cloning of three novel neuronal Cdk5 activator binding proteins. Gene 2000, 242:285-294.

62. Nagase T, Kikuno R, Nakayama M, Hirosawa M, Ohara O: Prediction of the coding sequences of unidentified human genes. XVIII. The complete sequences of 100 new CDNA clones from brain which code for large proteins in vitro. DNA Res 2000, 7:273-281.

63. Fong KW, Choi YK, Rattner JB, Qi RZ: CDK5RAP2 is a pericentriolar protein that functions in centrosomal attachment of the gamma-tubulin ring complex. Mol Biol Cell 2008, 19:115-125

64. Zhang X, Liu D, Lv S, Wang H, Zhong X, Liu B, Wang B, Liao J, Li J, Pfeifer GP, XU X: CDK5RAP2 is required for spindle checkpoint function. Cell Cycle 2009, 8:1206-1216.

65. Lucas EP, Raff JW: Maintaining the proper connection between the centrioles and the pericentriolar matrix requires Drosophila centrosomin. J Cell Biol 2007, 178:725-732.

66. Terada $Y$, Uetake $Y$, Kuriyama R: Interaction of Aurora-A and centrosomin at the microtubule-nucleating site in Drosophila and mammalian cells. $J$ Cell Biol 2003, 162:757-763.

67. Guernsey DL, Jiang H, Hussin J, Arnold M, Bouyakdan K, Perry S, BabineauSturk T, Beis J, Dumas N, Evans SC, Ferguson M, Matsuoka M, Macgillivray C, Nightingale M, Patry L, Rideout AL, Thomas A, Orr A, Hoffmann I, Michaud JL, Awadalla P, Meek DC, Ludman M, Samuels ME: Mutations in centrosomal protein CEP152 in primary microcephaly families linked to MCPH4. Am J Hum Genet 2010, 87:40-51.

68. Blachon S, Gopalakrishnan J, Omori Y, Polyanovsky A, Church A, Nicastro D, Malicki J, Avidor-Reiss T: Drosophila asterless and vertebrate Cep152 Are orthologs essential for centriole duplication. Genetics 2008, 180:2081-2094.

69. Saunders RD, Avides MC, Howard T, Gonzalez C, Glover DM: The Drosophila gene abnormal spindle encodes a novel microtubuleassociated protein that associates with the polar regions of the mitotic spindle. J Cell Biol 1997, 137:881-890.

70. Ponting CP: A novel domain suggests a ciliary function for ASPM, a brain size determining gene. Bioinformatics 2006, 22:1031-1035.

71. Kouprina N, Pavlicek A, Collins NK, Nakano M, Noskov VN, Ohzeki J, Mochida GH, Risinger Jl, Goldsmith P, Gunsior M, Solomon G, Gersch W, Kim JH, Barrett JC, Walsh CA, Jurka J, Masumoto H, Larionov V: The microcephaly ASPM gene is expressed in proliferating tissues and encodes for a mitotic spindle protein. Hum Mol Genet 2005, 14:2155-2165.

72. Craig R, Norbury C: The novel murine calmodulin-binding protein Sha1 disrupts mitotic spindle and replication checkpoint functions in fission yeast. J Cell Sci 1998, 111:3609-3619.

73. Darvish H, Esmaeeli-Nieh S, Monajemi GB, Mohseni M, GhasemiFirouzabadi S, Abedini SS, Bahman I, Jamali P, Azimi S, Mojahedi F, Dehghan A, Shafeghati Y, Jankhah A, Falah M, Soltani Banavandi MJ, GhaniKakhi M, Garshasbi M, Rakhshani F, Naghavi A, Tzschach A, Neitzel H, Ropers HH, Kuss AW, Behjati F, Kahrizi K, Najmabadi H: A clinical and molecular genetic study of 112 Iranian families with primary microcephaly. J Med Genet 2010, 47:823-828.

74. Bond J, Scott S, Hampshire DJ, Springell K, Corry P, Abramowicz MJ, Mochida GH, Hennekam RC, Maher ER, Fryns JP, Alswaid A, Jafri H, Rashid Y, Mubaidin A, Walsh CA, Roberts E, Woods CG: Protein truncating mutations in ASPM cause variable reduction in brain size. Am J Hum Genet 2003, 73:1170-1177.

75. Fish $J$, Kosodo Y, Enard W, Pääbo S, Huttner WB: Aspm specifically maintains symmetric proliferative divisions of neuroepithelial cells. Proc Natl Acad Sci USA 2006, 103:10438-10443.

76. Paramasivam M, Chang YJ, LoTurco JJ: ASPM and citron kinase co-localize to the midbody ring during cytokinesis. Cell Cycle 2007, 6:1605-1612.

77. Gurok U, Loebbert RW, Meyer AH, Mueller R, Schoemaker H, Gross G, Behl B: Laser capture micro dissection and microarray analysis of dividing neural progenitor cells from the adult rat hippocampus. Eur $J$ Neurosci 2007, 26:1079-1090.

78. Fujimori A, Yaoi T, Ogi H, Wang B, Suetomi K, Sekine E, Yu D, Kato T, Takahashi S, Okayasu R, Itoh K, Fushiki S: Ionizing radiation downregulates 
ASPM, a gene responsible for microcephaly in humans. Biochem Biophys Res Commun 2008, 369:953-957.

79. Zhong X, Liu L, Zhao A, Pfeifer GP, Xu X: The abnormal spindle-like, microcephaly-associated (ASPM) gene encodes a centrosomal protein. Cell Cycle 2005, 4:1227-1229.

80. Hagemann C, Anacker J, Gerngras S, Kühnel S, Said HM, Patel R, Kämmerer U, Vordermark D, Roosen K, Vince GH: Expression analysis of the autosomal recessive primary microcephaly genes $\mathrm{MCPH} 1$ (microcephalin) and MCPH5 (ASPM, abnormal spindle-like, microcephaly associated) in human malignant gliomas. Oncol Rep 2008, 20:301-308.

81. Riparbelli MG, Callaini G, Glover DM, Avides Mdo C: A requirement for the Abnormal Spindle protein to organise microtubules of the central spindle for cytokinesis in Drosophila. J Cell Sci 2002, 15:913-922.

82. do Carmo Avides M, Glover DM: Abnormal spindle protein, and the integrity of mitotic centrosomal microtubule organizing centers. Science 1999, 283:1733-1735.

83. Gonzalez C, Saunders RD, Casal J, Molina I, Carmena M, Ripoll P, Glover DM: Mutations at the asp locus of Drosophila lead to multiple free centrosomes in syncytial embryos, but restrict centrosome duplication in larval neuroblasts. J Cell Sci 1990, 96:605-616.

84. Pulvers JN, Bryk J, Fish JL, Wilsch-Bräuninger M, Arai Y, Schreier D, Naumann R, Helppi J, Habermann B, Vogt J, Nitsch R, Tóth A, Enard W, Pääbo $S$, Huttner WB: From the Cover: Mutations in mouse Aspm (abnormal spindle-like microcephaly associated) cause not only microcephaly but also major defects in the germline. Proc Natl Acad Sci USA 2010, 107:16595-16600.

85. Hung LY, Tang CJ, Tang TK: Protein 4.1 R-135 interacts with a novel centrosomal protein (CPAP) which is associated with the gamma-tubulin complex. Mol Cell Biol 2000, 20:7813-7825.

86. Hung LY, Chen HL, Chang CW, Li BR, Tang TK: Identification of a novel microtubule-destabilizing motif in CPAP that binds to tubulin heterodimers and inhibits microtubule assembly. Mol Biol Cell 2004, 15:2697-2706.

87. Chen CY, Olayioye MA, Lindeman GJ, Tang TK: CPAP interacts with 14-3-3 in a cell cycle-dependent manner. Biochem Biophys Res Commun 2006, 342:1203-1210.

88. Gul A, Hassan MJ, Hussain S, Raza Sl, Chishti MS, Ahmad W: A novel deletion mutation in CENPJ gene in a Pakistani family with autosomal recessive primary microcephaly. J Hum Genet 2006, 51:760-764.

89. Al-Dosari MS, Shaheen R, Colak D, Alkuraya FS: Novel CENPJ mutation causes Seckel syndrome. J Med Genet 2010, 47:411-414

90. Cho JH, Chang CJ, Chen CY, Tang TK: Depletion of CPAP by RNAi disrupts centrosome integrity and induces multipolar spindles. Biochem Biophys Res Commun 2006, 339:742-747.

91. Koyanagi M, Hijikata M, Watashi K, Masui O, Shimotohno K: Centrosomal P4.1-associated protein is a new member of transcriptional coactivators for nuclear factor-kappaB. J Biol Chem 280:12430-12437.

92. Basto R, Lau J, Vinogradova T, Gardiol A, Woods CG, Khodjakov A, Raff JW: Flies without centrioles. Cell 2006, 125:1375-1386.

93. Stevens NR, Raposo AA, Basto R, St Johnston D, Raff JW: From stem cell to embryo without centrioles. Curr Biol 2007, 17:1498-1503.

94. Kirkham M, Müller-Reichert T, Oegema K, Grill S, Hyman AA: SAS-4 is a C. elegans centriolar protein that controls centrosome size. Cell 2003, 112:575-587.

95. Dammermann A, Maddox PS, Desai A, Oegema K: SAS-4 is recruited to a dynamic structure in newly forming centrioles that is stabilized by the gamma-tubulin-mediated addition of centriolar microtubules. J Cell Biol 2008, 180:771-785

96. Karkera JD, Izraeli S, Roessler E, Dutra A, Kirsch I, Muenke M: The genomic structure, chromosomal localization, and analysis of SIL as a candidate gene for holoprosencephaly. Cytogenet Genome Res 2002, 97:62-67.

97. Aplan PD, Lombardi DP, Ginsberg AM, Cossman J, Bertness VL, Kirsch IR: Disruption of the human SCL locus by "illegitimate" V-(D)-J recombinase activity. Science 1990, 250:1426142-1426149.

98. Pfaff KL, Straub CT, Chiang K, Bear DM, Zhou Y, Zon LI: The zebra fish cassiopeia mutant reveals that SIL is required for mitotic spindle organization. Mol Cell Biol 2007, 27:5887-5897.

99. Campaner S, Kaldis P, Izraeli S, Kirsch IR: Sil phosphorylation in a Pin 1 binding domain affects the duration of the spindle checkpoint. Mol Cell Biol 2005, 25:6660-6672.
100. Izraeli S, Lowe LA, Bertness VL, Good DJ, Dorward DW, Kirsch IR, Kuehn MR: The SIL gene is required for mouse embryonic axial development and left-right specification. Nature 1999, 399:691-694.

101. Qamar R, Ayub Q, Mohyuddin A, Helgason A, Mazhar K, Mansoor A, Zerjal T, Tyler-Smith C, Mehdi SQ: Y-chromosomal DNA variation in Pakistan. Am J Hum Genet 2002, 70:1107-1124

102. Mehdi SQ, Qamar R, Ayub Q, Kaliq S, Mansoor A, Ismail M, Hammer MF, Underhill PA, Cavalli-Sforza LL: The origins of Pakistani populations: evidence from $Y$ chromosome markers. In Genomic diversity: applications in human population genetics. Edited by: Papiha SS, Deka R, Chakraborty R. New York Kluwer Academic/Plenum Publishers; 2002:83-90.

103. Cavalli-Sforza LL, Piazza A: Human genomic diversity in Europe: a summary of recent research and prospects for the future. Eur J Hum Genet 1993, 1:3-18

104. Firasat S, Khaliq S, Mohyuddin A, Papaioannou M, Tyler-Smith C, Underhill PA, Ayub Q: Y-chromosomal evidence for a limited Greek contribution to the Pathan population of Pakistan. Eur J Hum Genet 2007, 15:121-126.

105. Kousar R, Nawaz H, Khurshid M, Ali G, Khan SU, Mir H, Ayub M, Wali A, Ali N, Jelani M, Basit S, Ahmad W, Ansar M: Mutation analysis of the ASPM gene in 18 Pakistani families with autosomal recessive primary microcephaly. J Child Neurol 2010, 25:715-720.

106. Dorus S, Vallender EJ, Evans PD, Anderson JR, Gilbert SL, Meadowland M, Wyckoff GJ, Malcom CM, Lahn BT: Accelerated evolution of nervous system genes in the origin of Homo sapiens. Cell 2004, 119:1027-1040,

107. Evans PD, Anderson JR, Vallender EJ, Gilbert SL, Malcom CM, Dorus S, Lahn BT: Adaptive evolution of ASPM, a major determinant of cerebral cortical size in humans. Hum Mol Genet 2004, 13:489-494.

108. Evans PD, Anderson JR, Vallender EJ, Choi SS, Lahn BT: Reconstructing the evolutionary history of microcephalin, a gene controlling human brain size. Hum Mol Genet 2004, 13:1139-1145.

109. Evans PD, Gilbert SL, Mekel-Bobrov N, Vallender EJ, Anderson JR, Vaez Azizi LM, Tishkoff SA, Hudson RR, Lahn BT: Microcephalin, a gene regulating brain size, continues to evolve adaptively in humans. Science 2005, 309:1717-1720.

110. Mekel-Bobrov N, Gilbert SL, Evans PD, Vallender EJ, Anderson JR, Hudson RR, Tishkoff SA, Lahn BT: Ongoing adaptive evolution of ASPM, a brain size determinant in Homo sapiens. Science 2005, 309:1720-1722.

111. Currat M, Excoffier L, Maddison W, Otto SP, Ray N, Whitlock MC, Yeaman S: Comment on "Ongoing adaptive evolution of ASPM, a brain size determinant in Homo sapiens" and "Microcephalin, a gene regulating brain size, continues to evolve adaptively in humans". Science 2006, 313:172-179.

112. Mekel-Bobrov N, Posthuma D, Gilbert SL, Lind P, Gosso MF, Luciano M, Harris SE, Bates TC, Polderman TJ, Whalley LJ, Fox H, Starr JM, Evans PD, Montgomery GW, Fernandes C, Heutink P, Martin NG, Boomsma DI, Deary IJ, Wright MJ, de Geus EJ, Lahn BT: The ongoing adaptive evolution of ASPM and Microcephalin is not explained by increased intelligence. Hum Mol Genet 2007, 16:600-608.

113. Rushton JP, Vernon PA, Bons TA: No evidence that polymorphisms of brain regulator genes Microcephalin and ASPM are associated with general mental ability, head circumference or altruism. Biol Lett 2007, 3:157-160

114. Yu F, Hill RS, Schaffner SF, Sabeti PC, Wang ET, Mignault AA, Ferland RJ, Moyzis RK, Walsh CA, Reich D: Comment on "Ongoing adaptive evolution of ASPM, a brain size determinant in Homo sapiens". Science 2007, 316:370-375

115. Wang JK, Li Y, Su B: A common SNP of MCPH1 is associated with cranial volume variation in Chinese population. Hum Mol Genet 2008, 17:1329-1335.

116. Uniprot protein website. [http://www.uniprot.org/uniprot/?query=domain: $\% 221 \mathrm{Q}+$ domain*\%22].

117. Woods RP, Freimer NB, De Young JA, Fears SC, Sicotte NL, Service SK, Valentino DJ, Toga AW, Mazziotta JC: Normal variants of Microcephalin and ASPM do not account for brain size variability. Hum Mol Genet 2006, 15:2025-2029

118. Rivero O, Sanjuán J, Moltó MD, Aguilar EJ, Gonzalez JC, de Frutos R, Nájera C: The microcephaly ASPM gene and schizophrenia: A preliminary study. Schizophr Res 2006, 84:427-429.

119. Dediu D, Ladd DR: Linguistic tone is related to the population frequency of the adaptive haplogroups of two brain size genes, ASPM and Microcephalin. Proc Natl Acad Sci USA 2007, 104:10944-109449. 
120. Montgomery SH, Capellini I, Venditti C, Barton RA, Mundy NI: Adaptive evolution of four microcephaly genes and the evolution of brain size in anthropoid primates. Mol Biol Evol 2011, 28:625-638.

doi:10.1186/1750-1172-6-39

Cite this article as: Mahmood et al:: Autosomal recessive primary

microcephaly (MCPH): clinical manifestations, genetic heterogeneity

and mutation continuum. Orphanet Journal of Rare Diseases 2011 6:39.

Submit your next manuscript to BioMed Central and take full advantage of:

- Convenient online submission

- Thorough peer review

- No space constraints or color figure charges

- Immediate publication on acceptance

- Inclusion in PubMed, CAS, Scopus and Google Scholar

- Research which is freely available for redistribution

Submit your manuscript at www.biomedcentral.com/submit 